\title{
KEPATUHAN DAN KOMITMEN KLIEN SKIZOFRENIA MENINGKAT SETELAH DIBERIKAN ACCEPTANCE AND COMMITMENT THERAPY DAN PENDIDIKAN KESEHATAN KEPATUHAN MINUM OBAT
}

\author{
Jek Amidos Pardede ${ }^{1,2 *}$, Budi Anna Keliat ${ }^{3}$, Ice Yulia ${ }^{3}$
}

1. Universitas Sari Mutiara Indonesia, Medan 20123, Indonesia

2. Program Studi Magister, Fakultas Ilmu Keperawatan, Universitas Indonesia, Depok 16424, Indonesia

3. Fakultas Ilmu Keperawatan, Universitas Indonesia, Depok 16424, Indonesia

*E-mail: jekpardedemi@ rocketmail.com

\begin{abstract}
Abstrak
Masalah keperawatan skizofrenia terbanyak adalah risiko perilaku kekerasan, halusinasi, dan harga diri rendah, dengan 55\% mengalami kekambuhan karena tidak patuh minum obat. Penelitian ini bertujuan untuk mengetahui pengaruh Acceptance and Commitment Therapy (ACT) dan pendidikan kesehatan kepatuhan minum obat terhadap gejala, kemampuan menerima dan berkomitmen klien skizofrenia. Penelitian ini menggunakan desain quasi eksperimental preposttest with control group, dengan jumlah sampel 90 orang klien skizofrenia yang dibagi menjadi 3 kelompok. Hasil penelitian ini ditemukan penurunan gejala risiko perilaku kekerasan, halusinasi dan harga diri rendah serta peningkatan kemampuan menerima dan berkomitmen pada pengobatan dan kepatuhan klien skizofrenia yang mendapatkan ACT dan pendidikan kesehatan kepatuhan minum obat lebih besar secara bermakna dibandingkan kelompok yang hanya mendapatkan terapi ACT $(\mathrm{p}<0,05)$. Terapi ACT dan pendidikan kesehatan kepatuhan minum obat direkomendasikan sebagai terapi keperawatan klien skizofrenia dengan risiko perilaku kekerasan, halusinasi dan harga diri rendah.
\end{abstract}

Kata Kunci: Acceptance and Commitment Therapy (ACT), pendidikan kesehatan kepatuhan minum obat, skizofrenia

\begin{abstract}
Compliance and Commitment to Clients Schizophrenia Increased After Given Acceptance and Commitment Therapy (ACT) and Education Health Medication Adherence. Schizophrenia nursing problems most commonly found is the risk of violent behavior, hallucinations, and low self esteem. Found 55\% of client risk violent behavior, hallucinations, and low self-esteem who have a relapse and medication adherence. This study aims to obtain the effects Acceptance and Commitment Therapy and Health Education adherence to symptoms, ability to accept and commit to treatment and compliance in schizophrenia clients Mental Hospital of Medan, North Sumatra. This research design quasiexperimental pre-test post-test with control group. This sampling technique was purposive sampling, where the sample is 90 clients with schizophrenia, 30 the intervention group were given Acceptance and Commitment Therapy and medication adherence health education, intervention group were given 30 Acceptance and Commitment Therapy and 30 control group. Results of this study found a reduction in symptoms risk of violent behavior, hallucinations, and low selfesteem and increased ability to accept and commit to the treatment of schizophrenia and compliance client who gets Acceptance and Commitment Therapy and health education medication adherence was significantly greater than the group that only get Acceptance and Commitment Therapy ( $p<0,05)$. Acceptance and commitment therapy and medication adherence health education recommended as a therapeutic nursing and therapy support advanced nursing care for clients in the risk of schizophrenia with violent behavior, hallucinations, and low self esteem.
\end{abstract}

Keywords: Acceptance and Commitment Therapy (ACT), health education medication adherence, schizophrenia

\section{Pendahuluan}

Skizofrenia adalah sekelompok reaksi psikotik yang memengaruhi berbagai area fungsi individu, termasuk berpikir, berkomunikasi, menerima, menginterpretasikan realitas, merasakan dan me- nunjukkan emosi (Isaacs, 2005). Rhoads (2011) menambahkan definisi skizofrenia yaitu penyakit kronis, parah, dan melumpuhkan, gangguan otak yang ditandai dengan pikiran kacau, waham, halusinasi, dan perilaku aneh. 
Prevalensi skizofrenia diperkirakan 0,2\% meningkat menjadi $1,5 \%$ setara untuk pria dan wanita di semua tingkatan usia (Buchanan \& Carpenter, 2005 dalam Barlow \& Durand, 2011). National Institute of Mental Health (2008, dalam Shives, 2012), mengatakan 2-4 juta orang, atau 1,1\% dari populasi di bumi menderita skizofrenia atau gangguan yang mirip dengan skizofrenia yang merusak kesadaran diri bagi banyak individu tapi mereka tidak menyadari bahwa mereka sakit dan membutuhkan pengobatan. Statistik menunjukkan sekitar $40 \%$ jiwa (1,0 juta jiwa) tidak menerima perawatan psikiatri yang menyebabkan terjadinya tuna wisma, penahanan atau kekerasan.

Klien skizofrenia $70 \%$ mengalami halusinasi (Stuart, 2009). Halusinasi merupakan keadaan seseorang mengalami perubahan dalam pola dan jumlah stimulasi yang diprakarsai secara internal atau eksternal di sekitar dengan pengurangan, berlebihan, distorsi, atau kelainan berespon terhadap setiap stimulus (Townsend, 2009). Hal ini juga didukung oleh Fontaine (2009), menyatakan halusinasi dengar merupakan gejala skizofrenia yang paling sering dijumpai mencakup 50-80\% dari keseluruhan halusinasi. Halusinasi dapat menjadi suatu alasan mengapa klien melakukan tindakan perilaku kekerasan karena suara-suara yang memberinya perintah sehingga rentan melakukan perilaku yang tidak adaptif. Perilaku kekerasan merupakan respon maladaptif dari kemarahan, hasil dari kemarahan yang ekstrim atau panik. Perilaku kekerasan yang timbul pada klien skizofrenia diawali dengan adanya perasaan tidak berharga, takut, dan ditolak oleh lingkungan sehingga individu akan menyingkir dari hubungan interpersonal dengan orang lain (Stuart, 2009).

Klien skizofrenia sering juga mengalami kekambuhan karena kekambuhan adalah keadaan penyakit setelah berada pada periode pemulihan yang disebabkan tiga faktor yaitu: aspek obat, aspek pasien, dan aspek keluarga (Wardani, Hamid, \& Wiarsih, 2009). Klien menghentikan pengobatan karena merasa pengobatan sudah tidak diperlukan. Kegagalan dan ketidakpatuhan dalam meminum obat sesuai program adalah alasan paling sering dalam kekambuhan skizofrenia dan kembali masuk rumah sakit. Penyebab klien skizofrenia tidak teratur meminum obat yaitu karena adanya gangguan realitas dan ketidakmampuan mengambil keputusan, dan hospitalisasi yang lama memberi konsekuensi kemunduran pada klien (ditandai dengan hilangnya motivasi dan tanggung jawab, apatis, menghindar dari kegiatan dan hubungan sosial, kemampuan dasar sering terganggu, seperti perawatan mandiri dan aktifitas hidup seharian) (Wardani, et al., 2009). Oleh karena itu, perlu tindakan keperawatan yang komprehensif untuk menangani klien skizofrenia ini.

Beberapa penelitian telah dilakukan untuk menurunkan gejala perilaku kekerasan Pemberian Cognitive Behavior Therapy (CBT) pada klien skizofrenia dengan perilaku kekerasan dapat meningkatkan kemampuan kognitif dan perilaku klien (Wahyuni, 2010). Hasil penelitian lain menunjukkan adanya perbedaan penurunan tanda dan gejala klien perilaku kekerasan yang bermakna setelah diberikan CBT dan Rational Emotive Behavior Therapy (REBT) (Sudiatmika, Keliat, \& Wardani, 2011). Penelitian menggunakan Acceptance and Commitment Therapy (ACT) sangat efektif dalam menciptakan penerimaan, perhatian dan lebih terbuka dalam mengembangkan kemampuan yang dimiliki klien skizofrenia (Hayes \& Smith, 2005); dengan menurunkan gejala perilaku marah dan kekerasan (Twohig, 2009; Sulistiowati, Keliat, \& Wardani, 2012), serta memperbaiki gejala afektif, sosial halusinasi yang terjadi pada klien skizofrenia (Gaudiano \& Herbert, 2006). Hasil penelitian yang dilakukan oleh Sasmita, Keliat, dan Budiharto (2007) didapatkan hasil bahwa CBT dapat meningkatkan kemampuan kognitif 29,31\% dan kemampuan perilaku $22,4 \%$ pada klien skizofrenia dengan harga diri rendah. Hidayat, Keliat, dan Wardani (2011) menemukan penurunan gejala dan peningkatan kemampuan klien harga diri rendah yang mendapat CBT dan REBT lebih besar dari dibanding yang tidak mendapatkan CBT dan REBT $(\mathrm{p}<0,05)$. Beberapa penelitian yang dilakukan menunjukkan bahwa dengan menggunakan terapi keperawatan mampu untuk mengatasi skizofrenia dengan risiko perilaku kekerasan, halusinasi, dan harga diri rendah terutama dengan menggunakan Acceptance and Commitment Therapy (ACT). 
Berdasarkan hasil dari beberapa penelitian ini menunjukkan tindakan keperawatan spesialis sudah terbukti mampu menangani klien skizofrenia seperti yang sudah dipaparkan tetapi perlu diantisipasi untuk menghindari kekambuhan akibat ketidakpatuhan minum obat sehingga terapi keperawatan perlu dikombinasikan dengan pendidikan kesehatan kepatuhan minum obat. Pendidikan Kesehatan kepatuhan minum obat merupakan pemberian informasi kepada pasien untuk memengaruhi pasien agar patuh meminum obat sehingga tidak menimbulkan kekambuhan dan tidak kembali lagi kerumah sakit untuk rawat inap. Menurut Skiner (1938, dalam Notoatmodjo, 2007), kepatuhan minum obat pada penderita merupakan suatu perilaku terbuka. Dengan demikian dapat dikatakan kepatuhan minum obat adalah mengkonsumsi obat-obatan yang diresepkan dokter pada waktu dan dosis yang tepat karena pengobatan hanya akan efektif apabila penderita mematuhi aturan dalam penggunaan obat. Pemberian obat yang teratur dan sesuai dengan dosis, klien mampu sembuh dari penyakit ditambah dengan terapi keperawatan spesialis dan pendidikan kesehatan yang mengubah kognitif dan perilaku klien sehingga patuh minum obat.

\section{Metode}

Desain penelitian yang digunakan pada penelitian ini adalah "Quasi Eksperiment Pre-Posttest with Control Group" dengan memberikan ACT dan pendidikan kesehatan kepatuhan minum obat pada kelompok intervensi 1 , hanya ACT pada kelompok intervensi 2 . Klien yang dijadikan sampel adalah klien skizofrenia yang mengalami risiko perilaku kekerasan, halusinasi, dan harga diri rendah di sebuah rumah sakit di Medan yang memenuhi kriteria penelitian ini yakni: klien terdiagnosa skizofrenia, klien skizofrenia berusia 18-60 tahun, klien relaps/kambuh $\geq 1$ kali, klien masuk rumah sakit karena alasan perilaku kekerasan (marah-marah, amuk, mencederai diri sendiri, orang lain maupun lingkungan), klien dengan diagnosis keperawatan: risiko perilaku kekerasan, halusinasi, dan harga diri rendah, serta telah mendapatkan terapi generalis keperawatan, klien wajib screening untuk mengetahui tindakan terapi generalis, klien tenang atau tidak dalam perilaku amuk, klien dapat membaca dan menulis, dan klien bersedia menjadi responden dan mengikuti terapi serta pendidikan kesehatan yang diberikan.

Teknik pengambilan sampel yang digunakan dalam penelitian ini dengan teknik purposive sampling dengan jumlah sampel 90 responden. Sebanyak 30 reponden mendapatkan ACT dan pendidikan kesehatan minum obat (intervensi 1), 30 responden mendapatkan ACT (intervensi 2), dan 30 responden kelompok kontrol.

Kelompok intervensi 1, intervensi 2, dan kelompok kontrol sama-sama mendapatkan terapi generalis sesuai dengan standar yang berlaku di rumah sakit, dan untuk kelompok intervensi diberikan juga ACT sebanyak 4 sesi masingmasing selama 30-45 menit. Pada sesi 1: Klien dibimbing untuk mengidentifikasi kejadian buruk dan mengungkapkan pikiran, perasaan dan perilaku yang muncul akibat kejadian tersebut. Sesi 2: Klien mengidentifikasi dan memilih nilai hidupnya berdasarkan pengalaman sehingga dapat membantu menyelesaikan masalah yang dihadapi dan merubah pola pikir yang salah menjadi benar. Pada sesi 3: Klien berlatih menerima kejadian berdasarkan nilai yang sudah dipilih atau klien diajarkan mengklarifikasi nilai dan kemampuan yang dimiliki. Sesi 4: Klien melakukan komitmen terhadap nilai yang dipilih untuk merubah perilaku untuk mencegah kekambuhan.

Kelompok intervensi 1 juga mendapatkan pendidikan kesehatan kepatuhan minum obat yang terdiri dari 2 sesi masing-masing selama 25-30 menit. Sesi 1: Menjelaskan manajemen pengobatan untuk pasien skizofrenia dengan risiko perilaku kekerasan, halusinasi dan harga diri rendah. Sesi 2: Penetapan tujuan dan bentuk rencana tindakan.

Pengukuran gejala risiko perilaku kekerasan, halusinasi dan harga diri rendah pada setiap klien dilakukan pada awal. Penelitian menggunakan modifikasi versi Overt Aggression Scale (OAS), Launay-Slade Hallucination Scale (LSHS), dan Rosenberg Self Esteem Scale (RSES). Begitu juga untuk pengukuran kemampuan menerima dan berkomitmen pada pengobatan menggunakan 
Acceptance and Action Questionnaire (AAQ II; Hayes, Jason, Frank, Akihiko, \& Jason 2006) dan Kepatuhan pengukurannya menggunakan Medication Adherence Rating Scale for the psychoses (MARS; Thompson, Kulkarni, \& Sergejew, 2000).

Pengukuran risiko perilaku kekerasan menggunakan OAS terdiri dari 26 item, pengukuran halusinasi menggunakan LSHS terdiri dari 12 item dan pengukuran harga diri rendah menggunakan RSES terdiri dari 27 item yang didalamnya mengukur respon kognitif, afektif, psikomotor, dan sosial. Pada pengukuran observasi terdiri dari 15 item yang mengukur respon fisik. Pengukuran kemampuan menerima dan berkomitmen pada pengobatan menggunakan modifikasi dari (AAQ II; Hayes, et al., 2006) yang terdiri dari 16 pernyataan dan pengukuran kepatuhan minum obat menggunakan modifikasi MARS; (Thompson, et al., 2000) yang terdiri dari 20 pernyataan. Analisis gejala, kemampuan menerima dan berkomitmen pada pengobatan dan kepatuhan dilakukan dengan menggunakan paired t-test, Anova test dan correlation test.

\section{Hasil}

Hasil penelitian ini menunjukkan rerata rentang usia klien 35 tahun (19-58 tahun), memiliki frekuensi dirawat rerata 3 kali paling banyak 12 kali dan paling sedikit 2 kali. Klien berjenis kelamin laki-laki 47 orang dan 43 orang perempuan, berpendidikan tinggi 46 orang dan 44 orang berpendidikan rendah, klien yang bekerja 70 orang dan tidak bekerja 20 orang, menikah 40 orang dan 50 orang yang tidak menikah/cerai. Klien memiliki riwayat gangguan jiwa 79 orang dan 11 orang tidak memiliki riwayat gangguan jiwa.

Hasil uji kesetaraan menunjukkan variabel pendidikan, pekerjaan, dan status perkawinan memengaruhi kemampuan menerima dan berkomitmen pada pengobatan dan kepatuhan klien ( $p>0,05)$. Sementara untuk variabel jenis kelamin, dan riwayat gangguan jiwa tidak memengaruhi kemampuan menerima dan berkomitmen pada pengobatan dan kepatuhan klien $(\mathrm{p}<0,05)$.
Gambar 1 memperlihatkan gejala risiko perilaku kekerasan pada kelompok intervensi 1 sebelum diberikan ACT dan pendidikan kepatuhan minum obat 39,23 (35,99\%), intervensi 2 sebelum diberikan ACT 39,17 (35,93\%) dan kelompok kontrol 36,67 (33,64\%). Gejala risiko perilaku kekerasan pada kelompok intervensi 1 setelah diberikan ACT dan pendidikan kepatuhan minum obat 86,87 (79,70\%), intervensi 2 setelah diberikan ACT $79,33(72,78 \%)$ dan kelompok kontrol 44,27 $(39,61 \%)$. Hasil uji statistik menunjukkan ada perbedaan yang bermakna antara kelompok intervensi 1 , intervensi 2 , dan kelompok kontrol setelah pemberian terapi $(\mathrm{p}<0,05)$. Perubahan risiko perilaku kekerasan pada kelompok intervensi 1 yang diberikan ACT dan pendidikan kepatuhan minum obat 47,63 (43,71\%), intervensi 2 yang diberikan ACT 33,87 (36,85\%), dan kelompok kontrol 7,60 (5,94\%).

Gambar 2 memperlihatkan gejala halusinasi pada kelompok intervensi 1 sebelum diberikan ACT dan pendidikan kepatuhan minum obat 17,40 $(32,83 \%)$, intervensi 2 sebelum diberikan ACT 19,97 (37,67\%), dan kelompok kontrol 17,37 $(32,77 \%)$. Gejala halusinasi pada kelompok intervensi 1 setelah diberikan ACT dan pendidikan kepatuhan minum obat $46,50(87,73 \%)$, intervensi 2 setelah diberikan ACT $42,47(80,13 \%)$ dan kelompok kontrol 24,30 (43,33\%). Hasil uji statistik menunjukkan ada perbedaan yang bermakna antara kelompok intervensi 1, intervensi 2, dan kelompok kontrol setelah pemberian terapi $(\mathrm{p}<0,05)$. Perubahan halusinasi pada kelompok

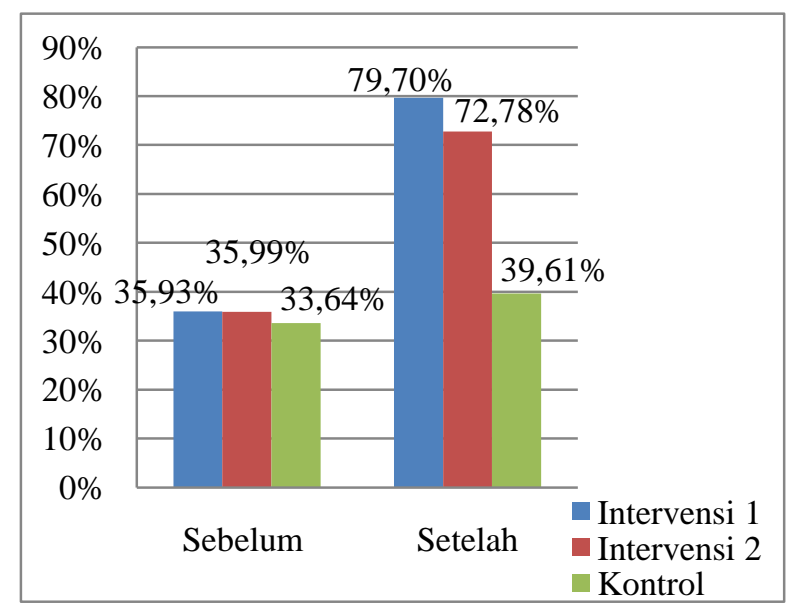

Gambar 1. Perubahan Risiko Perilaku 
intervensi 1 yang diberikan ACT dan pendidikan kepatuhan minum obat 29,10 (54,9\%), intervensi 2 yang diberikan ACT 22,50 (42,46\%), dan kelompok kontrol 2,83 (10,53\%).

Gambar 3 memperlihatkan gejala harga diri rendah pada kelompok intervensi 1 sebelum diberikan ACT dan pendidikan kepatuhan minum obat 45,70 $(39,05 \%)$, intervensi 2 sebelum diberikan ACT 48,10 (41,02\%), dan kelompok kontrol 44,37 $(37,92 \%)$. Hasil uji statistik menunjukkan ada ketidaksetaraan $(\mathrm{p}<0,05)$. Gejala harga diri rendah pada kelompok intervensi 1 setelah diberikan ACT dan pendidikan kepatuhan minum obat 94,40 (80,68\%), intervensi 2 setelah diberikan ACT 76,67 (65,53\%), dan kelompok kontrol 53,43 $(45,66 \%)$. Hasil uji statistik menunjukkan ada

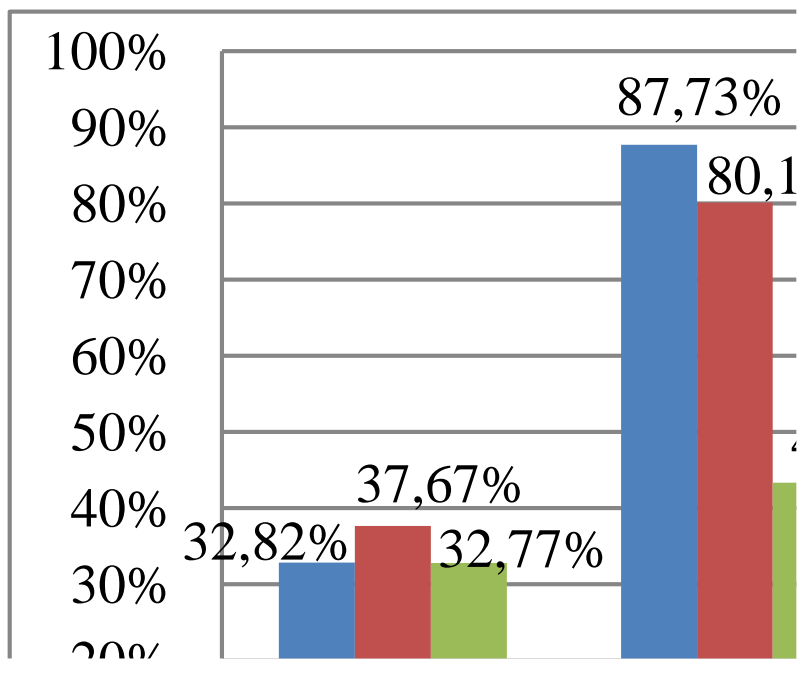

Gambar 2. Perubahan Halusinasi

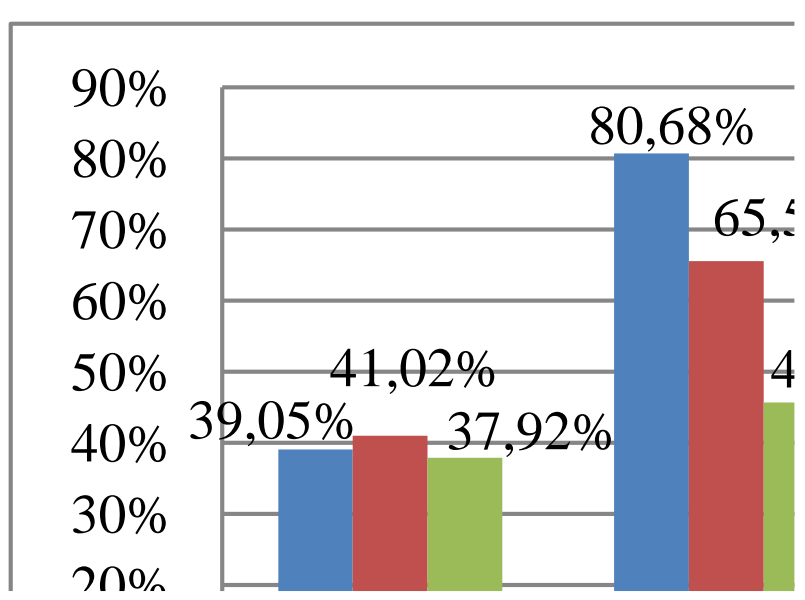

Gambar 3. Perubahan Harga Diri Rendah perbedaan yang bermakna antara kelompok intervensi 1 , intervensi 2 , dan kelompok kontrol setelah pemberian terapi $(\mathrm{p}<0,05)$. Perubahan harga diri rendah pada kelompok intervensi 1 yang diberikan ACT dan pendidikan kepatuhan minum obat 48,70 (41,63\%), intervensi 2 yang diberikan ACT 6,58 (24,51\%) dan kelompok kontrol 9,07 (7,74\%).

Gambar 4 memperlihatkan kemampuan menerima dan berkomitmen pada pengobatan pada kelompok intervensi 1 sebelum diberikan ACT dan pendidikan kepatuhan minum obat $24,37(38,08 \%)$, intervensi 2 sebelum diberikan ACT 24,37 $(38,08 \%)$ dan kelompok kontrol 24,30 (37,97\%). Hasil uji statistik menunjukkan ada kesetaraan ( $\mathrm{p}>0,05)$. Kemampuan menerima dan berkomitmen pada pengobatan pada kelompok intervensi 1 setelah diberikan ACT dan pendidikan kepatuhan minum obat 58,03 $(90,67 \%)$, intervensi 2 setelah diberikan ACT 50,47 (78,86\%) dan kelompok kontrol 27,23 (42,55\%). Hasil uji statistik menunjukkan ada perbedaan yang bermakna antara kelompok intervensi 1 , intervensi 2 , dan kelompok kontrol setelah pemberian terapi $(\mathrm{p}<0,05)$. Perubahan kemampuan menerima dan berkomitmen pada pengobatan pada kelompok intervensi 1 yang diberikan ACT dan pendidikan kepatuhan minum obat 33,68 (52,71\%), intervensi 2 yang diberikan ACT 26,10 (40,78\%), dan kelompok kontrol 2,93 $(4,58 \%)$.

Gambar 5 memperlihatkan kepatuhan pada kelompok intervensi 1 sebelum diberikan ACT dan pendidikan kepatuhan minum obat 7,33 (36,65\%),

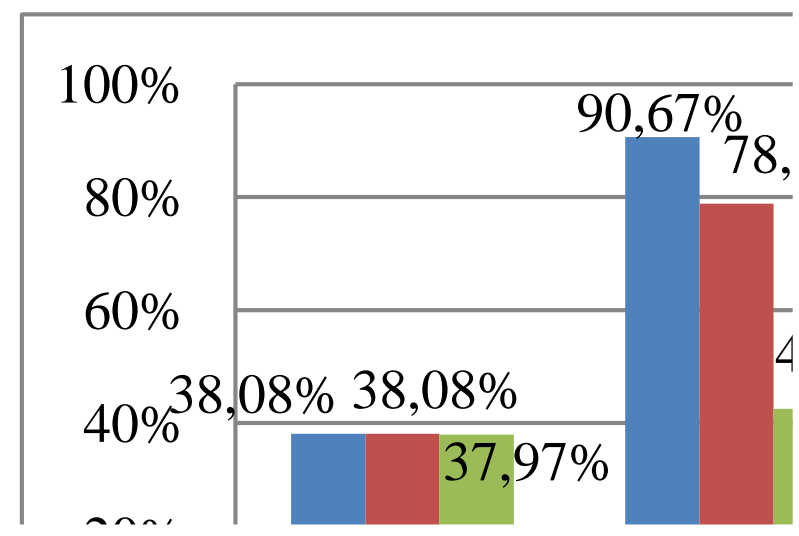

Gambar 4. Perubahan Kemampuan Menerima dan Berkomitmen pada Tritmen 
intervensi 2 sebelum diberikan ACT 7,30 (36,50\%), dan kelompok kontrol 7,37 (36,85\%). Hasil uji statistik menunjukkan ada kesetaraan ( $p>0,05)$. Kepatuhan pada kelompok intervensi 1 setelah diberikan ACT dan pendidikan kepatuhan minum obat 18,07 (90,35\%), intervensi 2 setelah diberikan ACT 13,00 (65\%), dan kelompok kontrol 9,70 (48,5\%). Hasil uji statistik menunjukkan ada perbedaan yang bermakna antara kelompok intervensi 1, intervensi 2, dan kelompok kontrol setelah pemberian terapi $(\mathrm{p}<0,05)$. Perubahan kepatuhan pada kelompok intervensi 1 yang diberikan ACT dan pendidikan kepatuhan minum obat $10,73(53,7 \%)$, intervensi 2 yang diberikan ACT 5,70 (28,5\%), dan kelompok kontrol 2,33 $(11,65 \%)$.

Analisis hubungan antara kemampuan menerima dan berkomitmen pada pengobatan dengan penurunan gejala risiko perilaku kekerasan, halusinasi, dan harga diri rendah dengan menggunakan uji correlation. Menurut Colton, dimana kekuatan

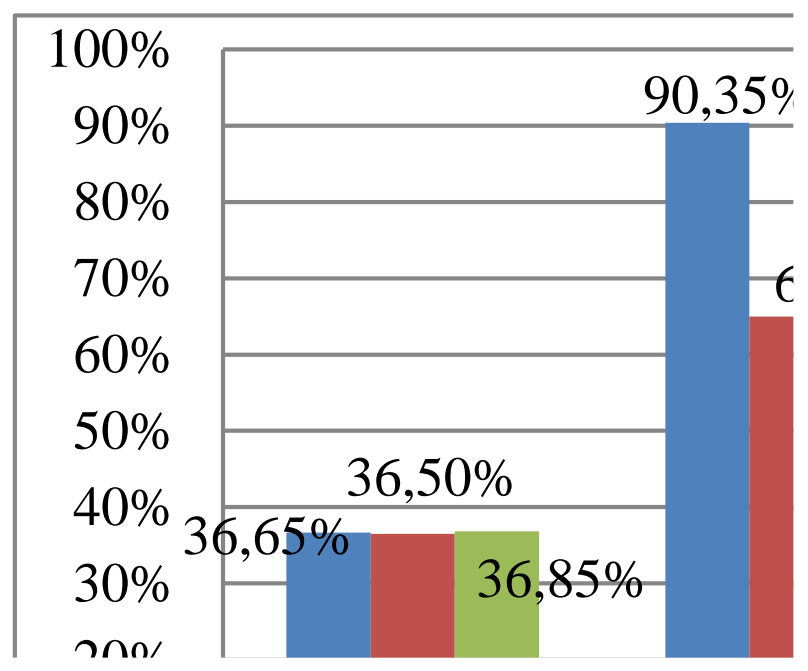

Gambar 5. Perubahan Kepatuhan hubungan dua variabel secara kualitatif dibagi dalam 4 area, meliputi: $r=0,00-0,25$ dikatakan tidak ada hubungan/hubungan lemah, $r=0,26-$ 0,50 dikatakan hubungan sedang, $r=0,51-0,75$ dikatakan hubungan kuat, dan $\mathrm{r}=0,76-1,00$ dikatakan hubungan sangat kuat/sempurna. Hasil analisis dapat dilihat pada Tabel 1.

Berdasarkan analisis pada Tabel 1 didapatkan ada hubungan yang kuat $(\mathrm{r}=0,590)$ antara kemampuan menerima dan berkomitmen pada pengobatan dengan penurunan gejala risiko perilaku kekerasan. Ada hubungan yang sedang $(\mathrm{r}=0,489)$ antara kemampuan menerima dan berkomitmen pada pengobatan dengan penurunan gejala halusinasi dan ada hubungan yang kuat $(r=0,714)$ antara kemampuan menerima dan berkomitmen pada pengobatan dengan penurunan gejala harga diri rendah. Hasil uji statistik didapatkan ada hubungan yang signifikan antara kemampuan menerima dan berkomitmen pada pengobatan dengan penurunan gejala harga diri rendah $(p<\alpha=0,05)$.

\section{Pembahasan}

Penelitian ini mendapatkan hasil yang meningkat setelah diberikan ACT dan pendidikan kesehatan minum obat, yaitu terjadi peningkatan rata-rata skor yang berarti membuktikan terjadi penurunan gejala pada responden skizofrenia dengan risiko perilaku kekerasan. Hasil penelitian ini menunjukkan terjadi penurunan antara sebelum dan setelah diberikan terapi, gejala risiko perilaku kekerasan pada kelompok yang diberikan ACT dan pendidikan kesehatan kepatuhan minum obat menurun $43,71 \%$, sedangkan kelompok yang hanya diberikan ACT gejala menurun $36,85 \%$ dan

Tabel 1. Hubungan Kemampuan Menerima dan Berkomitmen pada Pengobatan dengan Gejala Risiko Perilaku Kekerasan, Halusinasi, dan Harga Diri Rendah Klien Skizofrenia

\begin{tabular}{lccc}
\hline \multicolumn{1}{c}{ Variabel } & n & r & p \\
\hline $\begin{array}{l}\text { Kemampuan Menerima dan Berkomitmen pada Pengobatan } \\
\text { *Gejala Risiko Perilaku Kekerasan (RPK) }\end{array}$ & 60 & 0,590 & 0,000 \\
$\begin{array}{l}\text { Kemampuan Menerima dan Berkomitmen pada Pengobatan } \\
\text { *Gejala Halusinasi }\end{array}$ & 60 & 0,489 & 0,000 \\
$\begin{array}{l}\text { Kemampuan Menerima dan Berkomitmen pada Pengobatan } \\
\text { *Gejala Harga Diri Rendah (HDR) }\end{array}$ & 60 & 0,714 & 0,000 \\
\hline
\end{tabular}


kelompok yang tidak diberikan terapi menurun $5,94 \%$. Hasil penelitian menunjukkan ACT dan pendidikan kesehatan kepatuhan minum obat lebih ampuh untuk menurunkan gejala risiko perilaku kekerasan klien skizofrenia.

Perilaku kekerasan merupakan masalah yang sering terjadi pada klien skizofrenia sehingga beberapa terapi keperawatan dalam beberapa penelitian dilakukan untuk mengatasinya. Putri, Keliat, dan Nasution (2010) memberikan REBT pada klien dengan perilaku kekerasan secara bermakna mempunyai pengaruh menurunkan gejala perilaku kekerasan $15,35 \%$. Sudiatmika, et al. (2011) memberikan Rational Emotive Cognitive Behavior Therapy (RECBT) pada klien perilaku kekerasan yang menunjukkan adanya penurunan gejala setelah diberikan RECBT 30,06\%. Sedangkan Sulistiowati, et al. (2012) memberikan ACT pada klien skizofrenia dengan risiko perilaku kekerasan mengalami penurunan $53,49 \%$. Dalam hal ini terapi keperawatan sangat ampuh dalam penurunan gejala perilaku kekerasan sesuai dengan penelitian. Seperti terlihat di Gambar 6.

Penurunan gejala perilaku kekerasan klien skizofrenia berbeda-beda dari masing-masing terapi yang diberikan oleh peneliti, dan dapat dilihat pengaruh ACT yang dilakukan oleh Sulistiowati, et al. (2012) lebih besar penurunannya, begitu juga dengan yang dilakukan peneliti sendiri lebih besar penurunannya dari terapi yang lain karena peneliti sendiri menggunakan ACT. Hal ini dikarenakan ACT membantu klien menerima keadaannya dan kejadian yang membuat dirinya
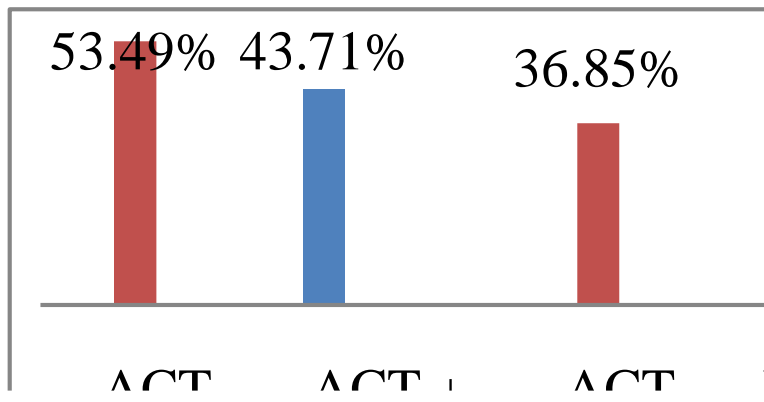

Gambar 6. Pengaruh REBT, RECBT, ACT dan $\mathrm{ACT}+$ Penkes terhadap Penurunan Gejala Risiko Perilaku Kekerasan berperilaku buruk atau tidak baik sehinggga klien harus berkomitmen merubah perilakunya untuk mencegah kekambuhan.

Penelitian ini mendapatkan hasil yang meningkat setelah diberikan ACT dan Pendidikan kesehatan kepatuhan minum obat, dimana terjadi peningkatan rata-rata skor berarti membuktikan terjadi penurunan gejala pada responden skizofrenia dengan halusinasi. Penurunan gejala halusinasi pada responden kelompok intervensi $154,9 \%$. Untuk kelompok intervensi 2 yang hanya mendapatkan ACT saja 42,46\% yang meliputi penurunan gejala kognitif $45,58 \%$, afektif $33,92 \%$, psikomotor $38,09 \%$, sosial 44,17\%, dan fisik 40,8\%. Namun, kelompok yang tidak mendapatkan terapi juga mengalami penurunan gejala $10,53 \%$ yang terdiri dari respon kognitif 5,33\%, afektif 4,75\%, psikomotor $2,08 \%$, sosial $1,16 \%$, dan fisik $8,02 \%$.

Penelitian Sudiatmika, et al. (2011) dengan memberikan RECBT pada klien halusinasi mampu menurunkan gejala 38,97\% dalam hal ini klien diajarkan untuk merubah fungsi berfikir klien ke arah yang positif yang akan membuat klien berperilaku konstruktif. Akan tetapi, Sulistiowati, et al. (2012) dalam penelitiannya menerangkan pemberian ACT pada klien skizofrenia dengan halusinasi mampu menurunkan gejala yang signifikan yaitu 40,78\%, yang meliputi gejala kognitif $53,67 \%$, afektif $60,78 \%$, psikomotor 54,785 , sosial $48,44 \%$, dan fisik $27,40 \%$.

Terapi keperawatan yang diberikan terbukti mampu menurunkan gejala halusinasi seperti yang sudah dilakukan dari beberapa penelitian, seperti terlihat pada Gambar 7. Hayes dan Smith (2005) menegaskan ACT mengajarkan klien untuk tidak menghindari tujuan hidupnya atau mampu menerima hidupnya dan berkomitmen terhadap dirinya sehingga mampu mengatasi masalahnya. Hal ini di dukung oleh Stuart (2009) yang mengatakan klien harus dapat bertahan dengan apa yang sudah dipilihnya ketika sudah berkomitmen sehingga dengan mampu menerima dan berkomitmen klien diharapkan tidak akan mengalami kekambuhan lagi. Harapannya terapi keperawatan seperti ACT perlu diberikan pada beberapa klien sehingga mampu menurunkan 
gejala penyakit, karena dapat dilihat ACT ditambah dengan pendidikan kesehatan kepatuhan minum obat mampu menurunkan gejala dengan baik. Penelitian ini mendapatkan hasil yang meningkat setelah diberikan ACT dan Pendidikan kesehatan kepatuhan minum obat, dimana terjadi peningkatan rata-rata skor berarti membuktikan terjadi penurunan gejala pada responden skizofrenia dengan harga diri rendah.

Penurunan gejala harga diri rendah pada responden kelompok intervensi $141,63 \%$ terdiri dari penurunan gejala kognitif $40,97 \%$, afektif $39,15 \%$, psikomotor $38,93 \%$, sosial $45,47 \%$, dan fisik 52,8\%. Untuk kelompok intervensi 2 yang hanya mendapatkan ACT saja $24,51 \%$, yang meliputi penurunan gejala kognitif $22,5 \%$, afektif $24,4 \%$, psikomotor $22,86 \%$, sosial $25,75 \%$, dan fisik $32,6 \%$. Namun, kelompok yang tidak mendapatkan terapi juga mengalami penurunan gejala $7,74 \%$ yang terdiri dari respon kognitif $9,32 \%$, afektif $1,42 \%$, psikomotor $5,72 \%$, sosial $11,43 \%$, dan fisik $24,8 \%$.

Penelitian lain juga mampu menurunkan gejala harga diri rendah 37,83\% dengan menggunakan CBT dan REBT atau RECBT yang dilakukan oleh Hidayat, et al. (2011). Hasil yang sama juga ditemukan oleh Sasmita, et al. (2007), CBT juga mampu memengaruhi respon kognitif dan perilaku klien skizofrenia dengan harga diri rendah dengan penurunan gejala $25,85 \%$. Berdasarkan kedua penelitian ini, RECBT lebih mampu untuk menurunkan gejala harga diri rendah, karena penelitian yang dilakukan dengan menggunakan CBT hanya memengaruhi kognitif dan perilaku sedangkan penelitian dengan RECBT memenga-

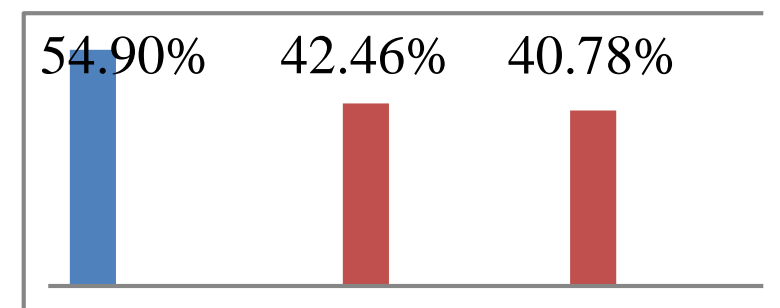

\section{ACT + ACT ACT I}

Gambar 7. Pengaruh CBT, RECBT, ACT, dan ACT + Penkes terhadap Penurunan Gejala Halusinasi

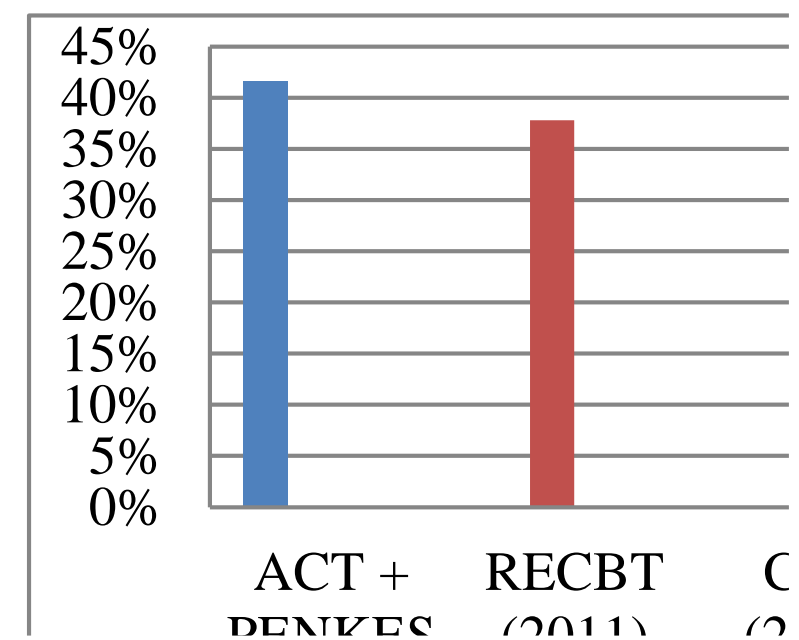

Gambar 8. Pengaruh CBT, RECBT, ACT, dan $\mathrm{ACT}+$ Penkes terhadap Penurunan Gejala Harga Diri Rendah

ruhi kognitif, afektif, psikomotor, sosial, dan fisik. Hasil penelitian beberapa peneliti terbukti bahwa terapi keperawatan mampu untuk menurunkan gejala harga diri rendah, dapat dilihat pada Gambar 8.

Hal ini dapat dilihat dari pemaparan hasil penelitian di atas, ACT dan pendidikan kesehatan kepatuhan minum obat lebih besar pengaruhnya dalam menurunkan gejala harga diri rendah dibandingkan dengan terapi lain. Sedangkan yang hanya menggunakan ACT tidak begitu berpengaruh dalam menurunkan gejala harga diri rendah pada penelitian ini sehingga dapat dikatakan dengan kombinasi ACT dan pendidikan kesehatan lebih baik dilakukan daripada hanya ACT saja.

\section{Kesimpulan}

Hasil penelitian membuktikan ACT yang diberikan pada klien skizofrenia dapat meningkatkan kemampuan menerima dan berkomitmen pada pengobatan. Hasil juga menunjukkan pendidikan kesehatan kepatuhan minum obat dapat meningkatkan kepatuhan klien untuk minum obat. Keduanya mampu menurunkan gejala risiko perilaku kekerasan, halusinasi, dan harga diri rendah klien skizofrenia sehingga dapat diaplikasikan sebagai terapi spesialis jiwa di rumah sakit maupun di komunitas. 
Hasil penelitian ini dapat dijadikan evidence based dalam membandingkan pengaruh beberapa terapi yang dapat diberikan pada klien skizofrenia maupun klien dengan diagnosa lain. Penelitian ini perlu dikembangkan dengan menggabungkan ACT dengan FPE (Family Psychoeducation) karena klien perlu sistem pendukung dari keluarga sebagai pemberi materiil maupun moril sehingga klien mau menerima dan berkomitmen pada pengobatan. Selain FPE, ACT juga dapat dikombinasikan dengan Logo terapi, Progressive Muscle Relaxation (PMR), dan lainnya. Pendidikan kesehatan kepatuhan minum obat juga perlu dikombinasikan dengan BT, CBT, REBT, RECBT, dan terapi lainnya sehingga klien yang dirawat mau patuh minum obat, yang artinya salah satu terapi yang disarankan perlu dikombinasikan dengan pendidikan kesehatan kepatuhan minum obat (BA, TN, PN).

\section{Referensi}

Barlow, D.H., \& Durand, V.M. (2011). Abnormal psychology: An integrative approach (5th Ed.). USA: Wadsworth Cengage Learning.

Fontaine, K.L. (2009). Mental health nursing (6th Ed.). New Jersey: Upper saddle River Pearson Prentice Hall.

Gaudiano, B.A., \& Herbert, J.D. (2006). Acute treatment of in patients with psychotic symptoms using ACT: Pilot result. Journal of Behavior Research and Therapy, 44, 415-437.

Hayes, S.C., \& Smith, S. (2005). Get out of your mind \& into your life: The new acceptance and commitment therapy. Oakland: New Harbinger.

Hayes, S., Jason, B.L., Frank, W.B., Akihiko, M., \& Jason, L. (2006). ACT: Model, processes, and outcomes. Journal of Behaviour Research and Therapy. 44, 1-25.

Hidayat, E., Keliat, B.A., \& Wardani, I.Y. (2011). Pengaruh CBT dan REBT terhadap klien dengan PK dan HDR di RSMM Bogor (Tesis, tidak dipublikasikan). FIK UI, Jakarta.

Isaacs, A. (2005). Keperawatan kesehatan jiwa \& psikiatri (3th Ed.). Jakarta: EGC.
Notoatmodjo, S. (2007). Pengantar pendidikan kesehatan dan ilmu perilaku. Jakarta: EGC.

Putri, D.E., Keliat, B.A., \& Nasution, Y. (2010) Pengaruh Rational Emotive Behaviour Therapy (REBT) terhadap klien perilaku kekerasan di RSMM Bogor. Jurnal Keperawatan Indonesia, Volume 15, No 3, November, 2012. Diperoleh dari http://jki.ui.ac.id/index.php/jki/article/view $/ 27 / 27$

Rhoads, J. (2011). Clinical consult for psychiatric mental health care. New York: Springer Publishing Company.

Sasmita, H., Keliat, B.A., \& Budiharto. (2007). Efektifitas Cognitive Behavioral Therapy (CBT) pada klien harga diri rendah di RSMM Bogor (Tesis, tidak dipublikasikan). FIK UI, Jakarta.

Shives, L.R. (2012). Basic concepts of psychiatric mental health nursing (8th Ed.). Philadelphia: Lippincott William \& Wilkins.

Stuart, G.W. (2009). Principles \& practice of psychiatric nursing (9th Ed.) Philadelphia: Elsevier Mosby.

Sudiatmika, I.K., Keliat, B.A., \& Wardani, I.Y. (2011). Efektivitas CBT dan REBT terhadap klien dengan $P K$ dan halusinasi di RSMM Bogor (Tesis, tidak dipublikasikan). FIK UI, Jakarta.

Sulistiowati, N.M.D., Keliat, B.A., \& Wardani, I.Y (2012). Pengaruh acceptance and commitment therapy terhadap gejala dan kemampuan klien dengan perilaku kekerasan dan halusinasi di RSMM Bogor (Tesis, tidak dipublikasikan). FIK UI, Jakarta.

Thompson, K.J., Kulkarni, A.A., \& Sergejew. (2000). Reliability and validity of a new Medication Adherence Rating Scale (MARS) for psychoses. Schizophrenia Research, 42, 241-247.

Townsend, M.C. (2009). Psychiatric mental health nursing: Concepts of care in evidencebased practice. Philadelphia: F.A Davis Company. 
Twohig, M. (2009). The aplication of acceptance and commitment therapy to OCD. Journal of Cognitive and Behavioral, 16, 18-28.

Wahyuni, S.E. (2010). Pengaruh cognitive behaviour therapy terhadap halusinasi pasien di Rumah Sakit Jiwa Pempropsu Medan (Tesis, tidak dipublikasikan). FIK UI, Jakarta.
Wardani, I.Y., Hamid, A.Y., \& Wiarsih,W. (2009). Pengalaman keluarga menghadapi ketidakpatuhan anggota keluarga dengan skizoprenia dalam mengikuti regimen terapeutik: Pengobatan (Tesis, tidak dipublikasikan). FIK UI, Jakarta. 